\title{
A Diabolical Dynasty
}

$\mathrm{T}$

HERE WAS ONCE a beautiful countess with a beautiful name Mélusine. Her husband, who ruled the county of Anjou in northern France, had good reason to be happy. His lovely wife had given him four fine sons and he was the envy of all his friends and enemies. But he was not completely content for all that. For one thing, nobody knew where the countess had come from. This had not mattered to the count when he had met her in a land far away and married her - it was enough that she was the most beautiful woman he had ever seen, and he had not troubled to enquire further about her past or her background. Now, though, he was starting to wonder, because the countess had one very odd habit that was making her husband increasingly uneasy. She only came rarely to church, and, when she did attend, she showed little sign of devotion and always left in a hurry straight after the Gospel reading. She was never there for the mass itself. People were starting to notice this and whisper about the countess's behaviour, so the count decided to find out what was going on. The next time the countess was in church, she got up to leave as usual after the Gospel, but four of her husband's men took hold of her and tried to force her down into her seat. The countess struggled and threw off the robe that the soldiers were grasping tightly. Then she picked up two of her four sons and in full view of the startled congregation she flew up into the air and out of the church through its highest window. She and her boys were never seen again. Mélusine, of course, was no mortal woman. She was the daughter of 
Satan himself, and she could not bear to look upon the consecrated host. As for her children, they were of the Devil's stock, and from the two she left behind were descended the Angevin kings of England - Henry II, Richard I and John.

So legend had it, at least. And it was a useful story. ${ }^{1}$ Contemporaries relied on it when they tried to explain the ferocious tempers and the tyrannical leanings common to all of these kings. Gerald of Wales, who told this tale and knew these men personally, confidently saw the moral of it: 'Since the root was so completely corrupt,' he asked,'how can fruitful or virtuous offspring come from it?' Henry II's father, Count Geoffrey of Anjou, had committed sexual crimes, Gerard alleged, whilst Henry's mother, the Empress Matilda, was guilty of bigamy. And when Henry himself had married Eleanor of Aquitaine, things only got worse. Eleanor was the product of an immoral union, and before marrying Henry and whilst still married to the French king Louis VII, she had had an affair with Henry's father. Such bad blood could only lead to violence and further wickedness.

Such violence took many forms and was directed towards opposing armies as well as individuals. But it was so pervasive and so inescapable that it must surely have had diabolical origins. The Angevin kings themselves were notorious sinners - avaricious and lustful, proud and angry, all died miserably, surely a sign of divine punishment for their carnal and worldly behaviour. Nonetheless, this was a legend that the kings themselves were also pleased to remember. Richard I is said to have joked about it often. He used it to explain why his family was so notoriously volatile, why he and his brothers quarrelled and fought so often with each other, with their father and with their mother. How could they be virtuous when their origins were so tainted, he asked? They had all come from the Devil, he said, and to the Devil they would all return. ${ }^{2}$

And in a sense Richard's prediction was correct. The story of the Angevin kings is very much one of 'rise and fall'. Henry II came to the English throne in 1154 after fifteen destructive years of civil war. However, when his son John died in 1216, England was once again being convulsed by internal conflict and foreign invasion. And between those dates, scandal and controversy were never far away. Thomas Becket's 
murder in 1170 usually claims the headlines, but there were other murders, too, as well as disastrous foreign wars and large-scale rebellions. Nevertheless, out of all this turmoil sprang some remarkable achievements. Henry II reconstructed a broken kingdom and has gained a reputation as 'the founder of the English common law'; Richard I was arguably England's most glamorous and impressive warrior-king; and, of course, there was Magna Carta, the product of rebellion to be sure, but above all the totemic foundation stone of the English constitution.

This story has been told many times before. Nevertheless, the period remains relatively unknown and unappreciated by a wider public. Most people have heard of Becket and Magna Carta, but beyond that there tends to be at best only a limited understanding of why the twelfth and early thirteenth centuries were formative times in the histories of England, the British Isles and Europe. Henry II, Richard and John were not just rulers of a single kingdom. They had aspirations to rule over the whole of Britain and Ireland, and at times they came close to doing so. But they were also rulers across the English Channel too. The county of Anjou in central France was their ancestral homeland (hence the 'Angevin' kings), and their duchies of Normandy and Aquitaine between them made up the greater part of northern and southern France. They were perhaps the richest and most powerful rulers of their day and, given the choice, they spent far more time in France than anywhere else. They were international figures, whose connections extended across Europe and the Mediterranean to the Middle East and beyond. So, at a time when the United Kingdom's own future is as uncertain as its relationship with the European mainland, it is important to remember that the twelfth and early thirteenth centuries constituted an era like no other. This was a period when England was as integrated as it has ever been into the wider international landscape, and when the kingdom was simply one part of a much greater political entity known to historians as the Angevin Empire.

Individual biographies of these kings abound, as do general histories of their reigns. This is the conventional way of writing about these events, through the lives of the rulers; inevitably so, given the nature of the source material that survives. The chroniclers focused their attention on the exploits of the leading figures, and the administrative records 
come almost exclusively from the royal archives. But this story is about more than the kings and queens, for other remarkable individuals also played a significant role. It is those stories which I have tried to uncover here and it is through the careers of these important but less well-known men and women that I have tried to describe what happened during this crucial time. This has been problematic for various reasons. Most obviously, the choice of subjects is severely limited by the available evidence and it has only been possible to write about people who moved in the upper levels of society - the children of the rulers or leading nobles and clerics who regularly, if not always frequently, caught the attention of contemporary writers or featured in the records of government. Even then, the evidence is patchy and inconsistent; there are large gaps and many uncertainties. And, more frustratingly still, the fish in this already small pool are overwhelmingly male. Unless she was a queen or a saint, it is very difficult indeed to reconstruct the life of a woman from this period to any telling degree, especially if the purpose of the exercise is to consider wider political developments through her experiences. The lives of the two women featured here - Princess Joan (sister of Richard I) and Nicola de la Haye - are indeed remarkable in allowing this to be done.

But why 'the long twelfth century'? It would have been possible to start this book with Henry II, with his rise to power, perhaps, or even his accession to the English throne in 1154. However, none of those developments or events is really understandable without a longer, deeper focus. Historians are tyrannised by dates, and by the attractions of neatly book-ended time periods. However, there is some sense in viewing the period 1066 to 1216, from an English point of view at least, as relatively self-contained. Whatever arguments still rage about the significance of the Norman Conquest, 1066 was an important year: it is meaningful to say that one era in English history ended then and that another one began. The same goes, albeit less decisively perhaps, for 1216. There was no change in dynasty or in the nationality of England's rulers (although these things nearly did happen), but the appearance of Magna Carta on the political scene and the death of John did in some fundamental ways mark the end of one kind of ruling system and the beginnings of another. Having said all this, I have given much greater weight here to the second 
half of this period. The years up to 1100 are dealt with only in passing, and the first half of my long century is covered by just the first two of my ten chapters. By contrast, the final four chapters cover the last seventeen years, the reign of King John. With the eighth centenaries of Magna Carta (2015) and of John's death (2016) in mind, and with so many good tales to tell, this emphasis felt justified.

So, despite some considerable difficulties, it has been possible to put the men and women who feature in these tales at the centre of the broader narrative in what I hope is a fresh and unusual way. Each chapter begins with a more or less contemporary anecdote about the individual concerned. Some of these anecdotes are based on verifiable evidence, whilst others read more like yarns or fables than credible accounts of actual events. But even if, to a modern reader, a few of these stories appear 'more true' than the rest, they all evoke and reveal important things about the characters they describe, the preoccupations of their authors and the times in which they all lived. Each anecdote is followed by a short explanation of the relevant wider context within which the main events of the chapter take place and an account of the issues that emerge, before the main character takes centre stage again for the rest of his or her tale. Their stories are truly gripping in their own right, and without exception these were extraordinary men and women. They are revealed here as recognisable human beings, noble and brave, flawed and fallible, trying to exercise control whilst subject to forces over which they held no sway. All of them were at the centre of momentous events, and the rise and fall of the Angevin Empire can be seen through their eyes. 


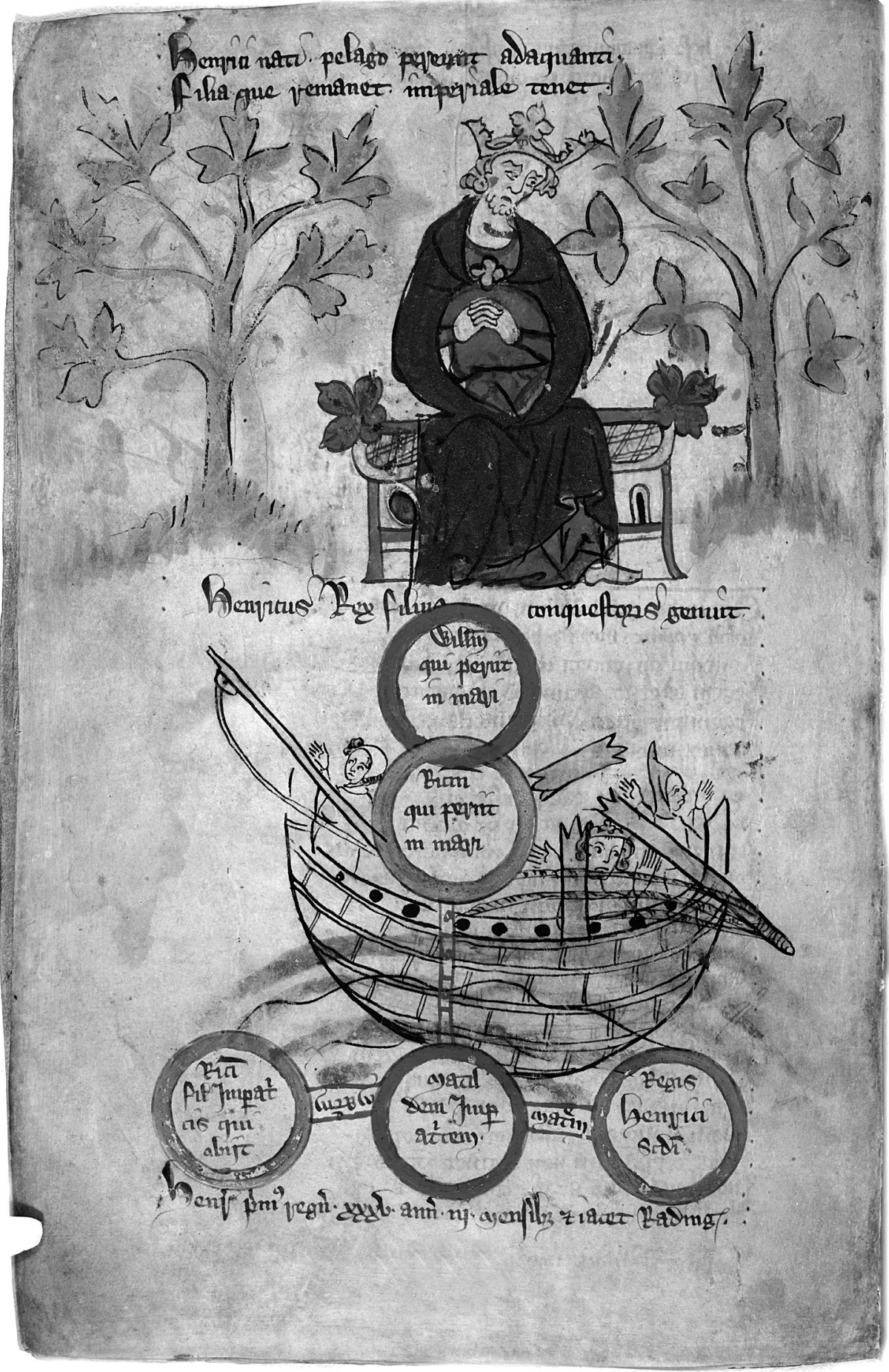

1. In 1120 Henry I's son William Atheling was drowned in the wreck of the White Ship, and civil war followed the resulting succession crisis. In this image from the fourteenth century the king mourns as the ship breaks up and sinks. 


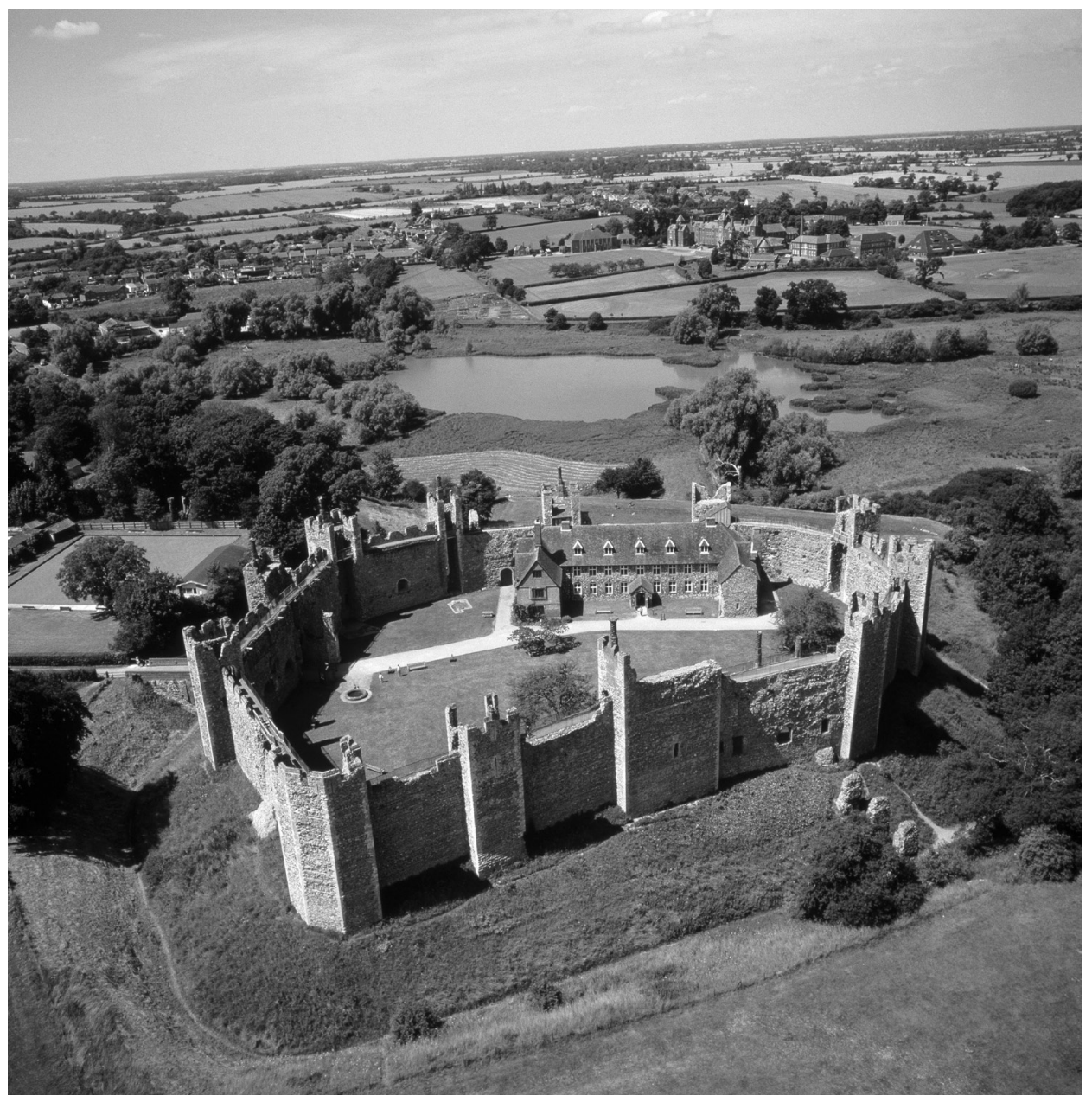

2. Framlingham Castle, Hugh Bigod's Suffolk powerbase, as it looks today. 


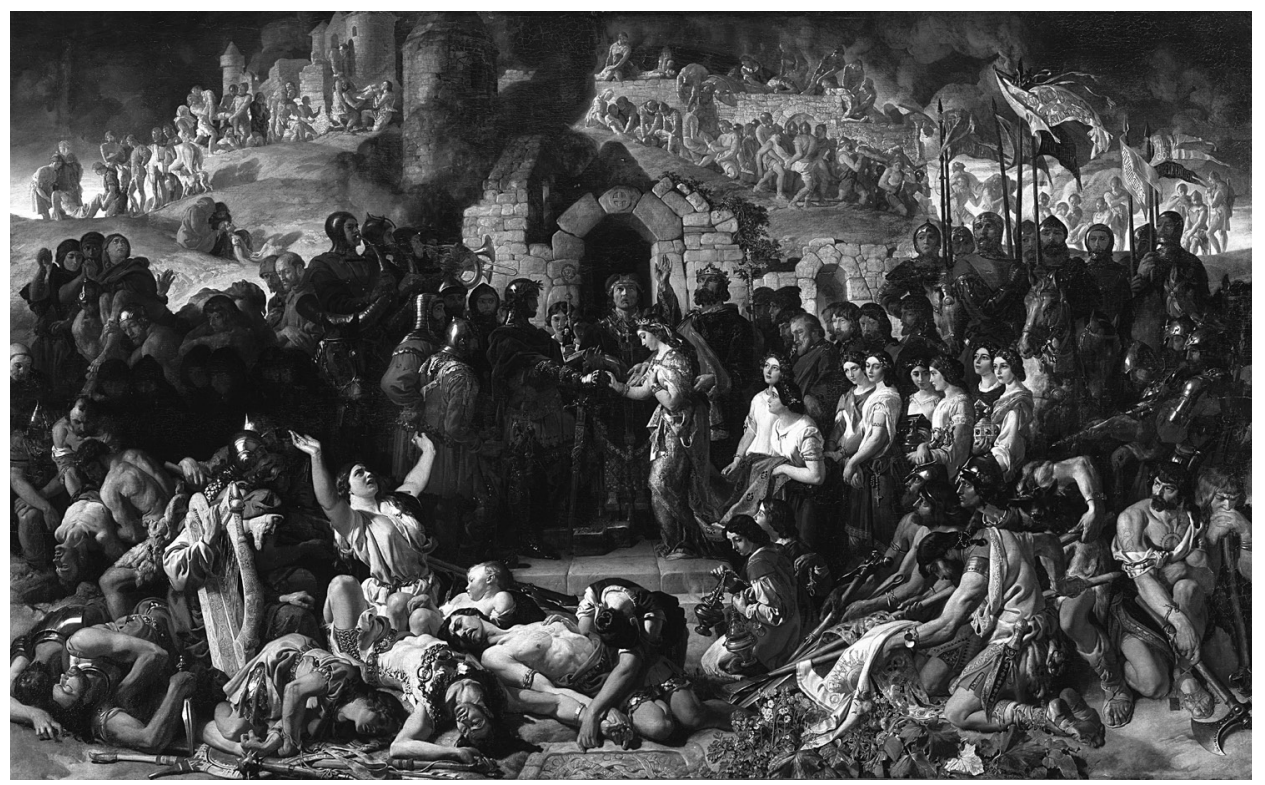

3. In return for agreeing to help Dermot MacMurrough retake his kingdom of Leinster, Strongbow was married to Dermot's daughter Aife in 1170 . This nineteenth-century interpretation by Daniel Maclise has the wedding taking place against the backdrop of the English siege of Waterford.

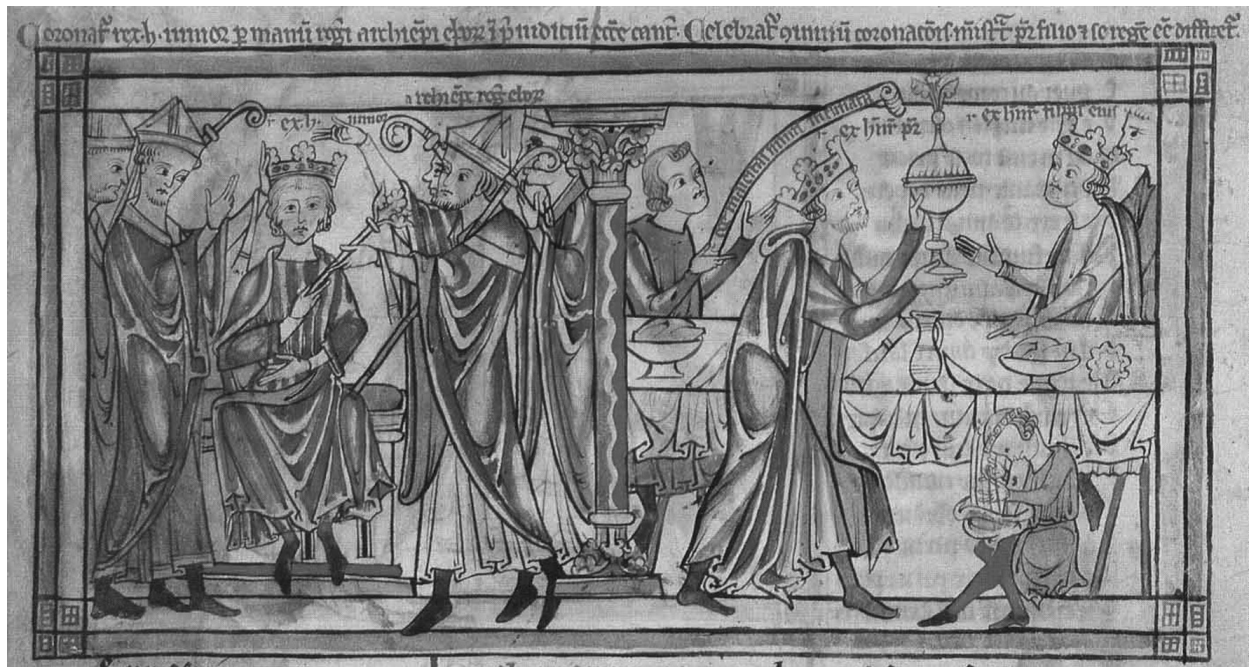

4. This thirteenth-century image shows Roger, archbishop of York crowning Henry the Young King in 1170. At the celebration banquet afterwards, the prince is waited on by his father, King Henry II. 


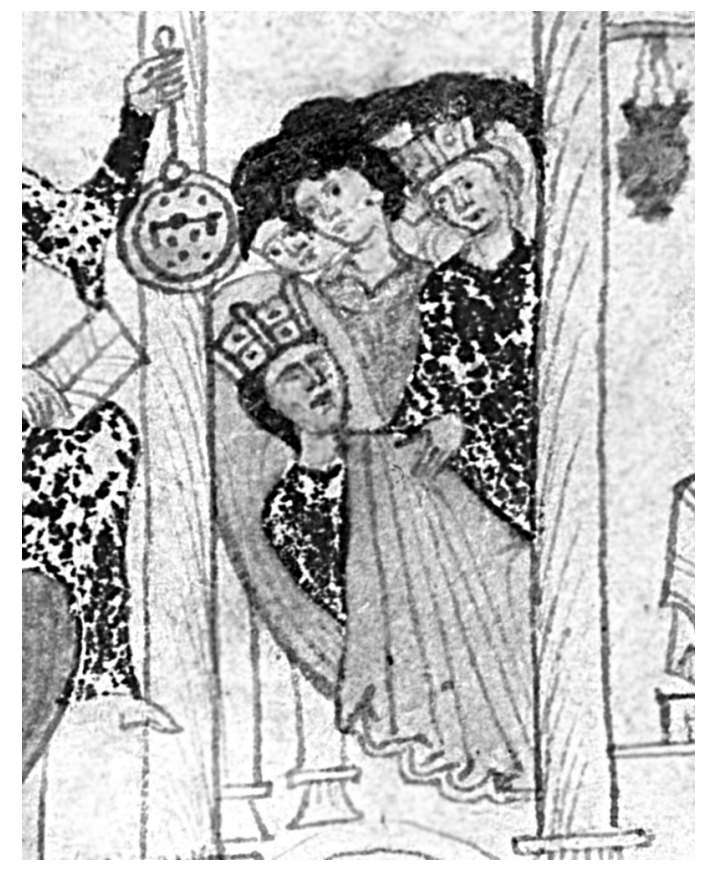

6. Monreale Cathedral was built by King William II of Sicily between 1174 and 1182. The cathedral's magnificent series of mosaics includes this portrait of Thomas Becket, perhaps the first image of him to be made after his martyrdom in 1170.

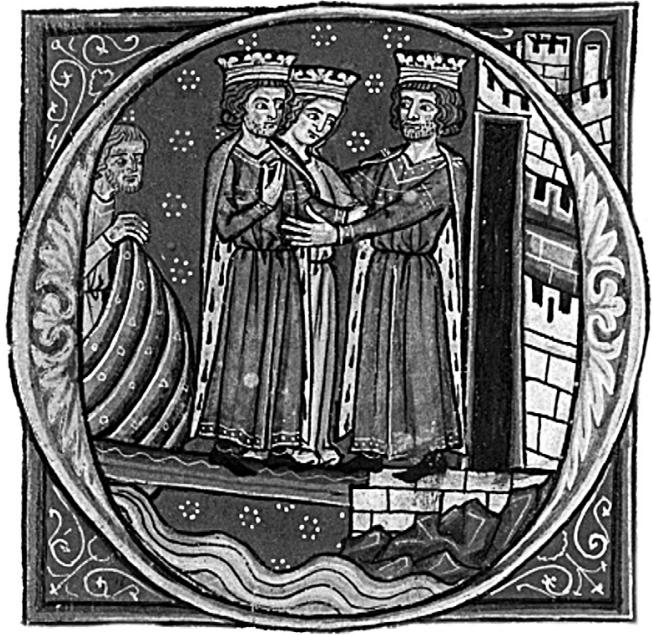

5. King William II of Sicily, Princess Joan's first husband, died in 1189. In this late twelfth-century chronicle he is depicted on his death-bed. The crowned figure standing to the right of the dying king is surely Joan looking on.

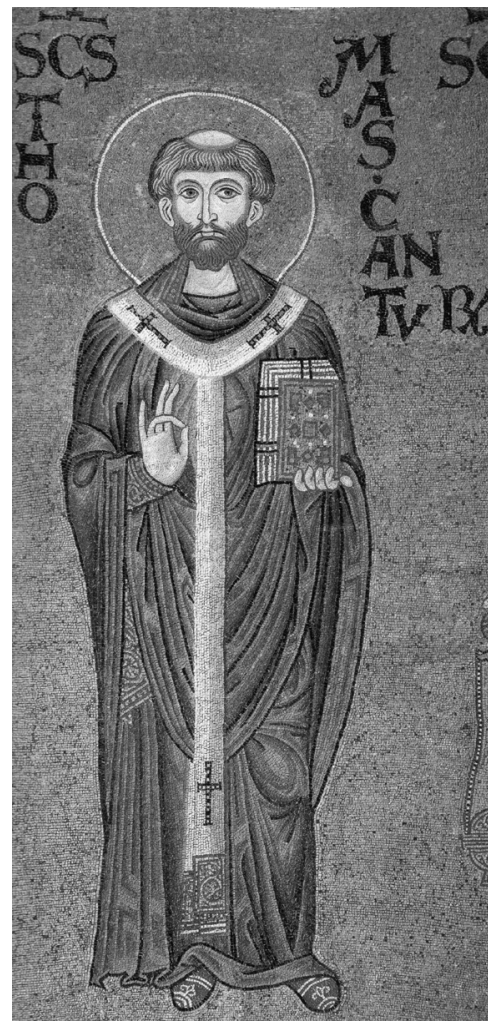

7. King Richard I and his sister Joan of Sicily arrived at Acre in the Holy Land in 1191. In this thirteenth-century history of the crusades they are shown meeting King Philip II of France at the gates of the city. Philip was reportedly struck by Joan's beauty. 


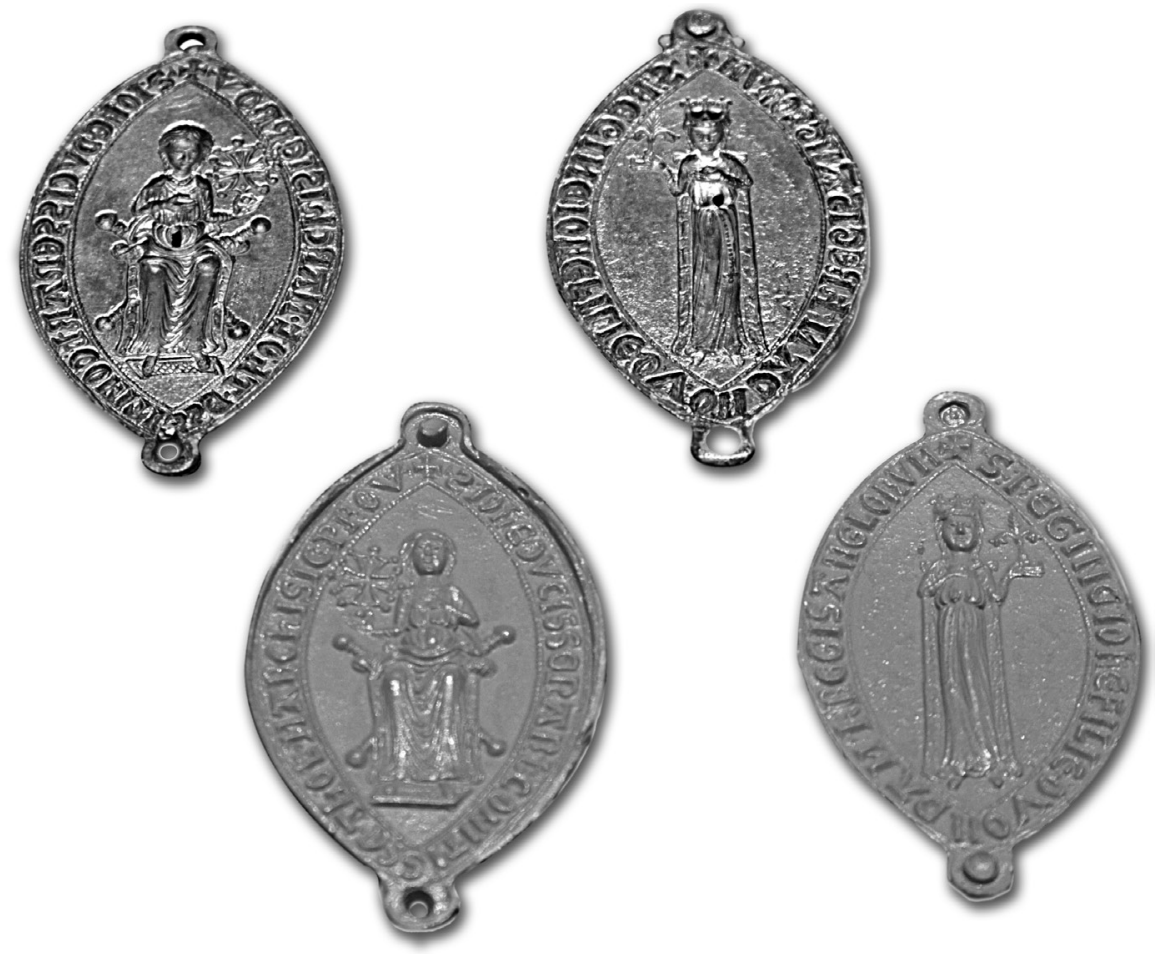

8. Joan's silver seal-die (with accompanying impressions in red wax), made in two pieces in the late 1190s. On the left she holds the cross of Toulouse and around the edge she is described as 'Duchess of Narbonne, Countess of Toulouse and Marchioness of Provence'. On the right she holds a sceptre with fleur-de-lis at the end. Around the edge she is described as 'Queen Joan, daughter of the late king of the English'.

9. Duke Arthur of Brittany disappeared whilst in the custody of his uncle King John in 1203. It is not clear how he died, but this eighteenth-century depiction by William Hamilton of his murder may rightly hold John personally responsible for Arthur's fate.

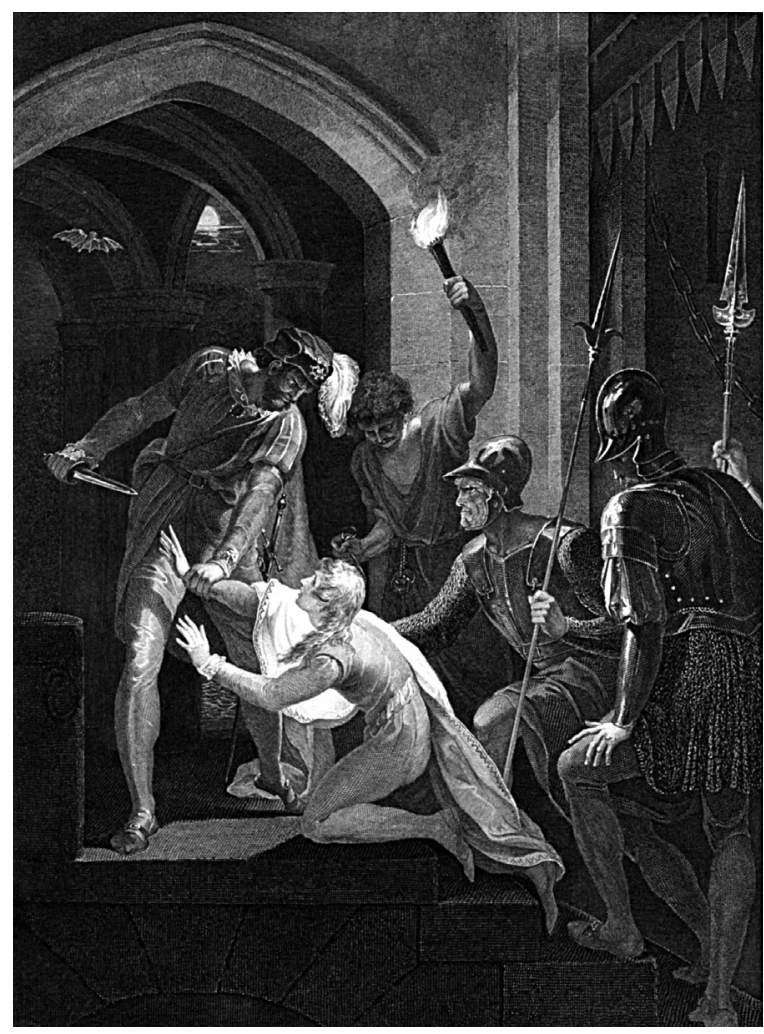




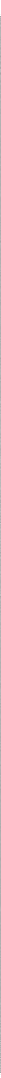

10. In this engraving by John George Murray, based on the tale told by Roger of Wendover, Archbishop Stephen Langton shows a copy of Henry I's Coronation Charter to a group of barons in the abbey at Bury St Edmunds. Although dressed in medieval clothing, each baron in the engraving was a named nineteenth-century nobleman. They saw themselves as the descendants of the Runnymede barons, responsible for the defence of the principles enshrined in Magna Carta. 


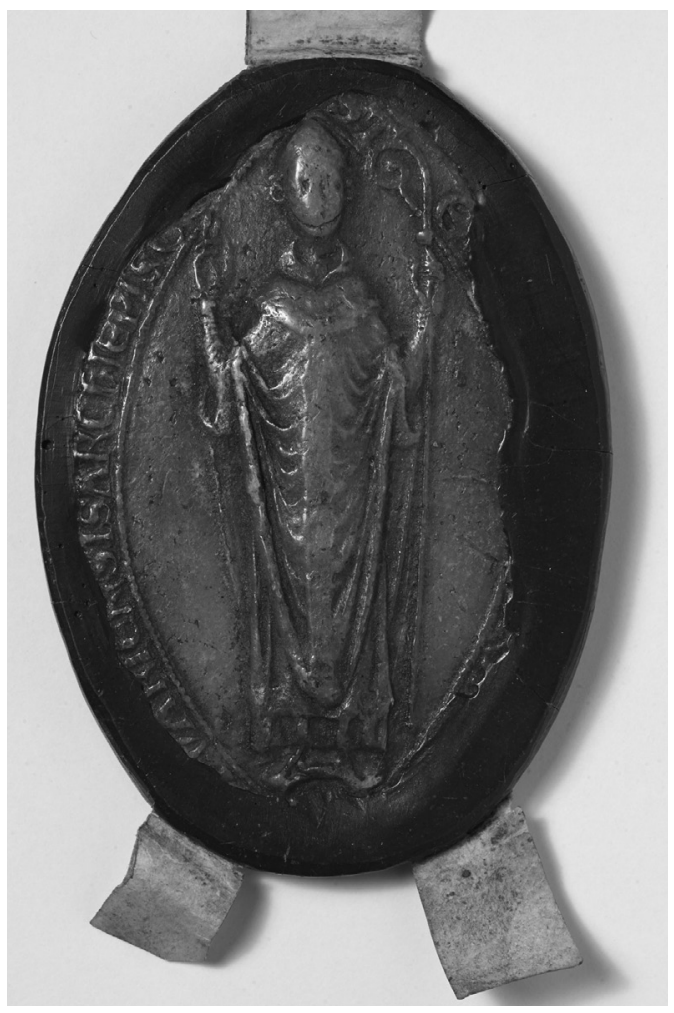

11. The seal of Stephen Langton, archbishop of Canterbury. On the reverse is a depiction of the martyrdom of Thomas Becket. By featuring this image on his own seal, Langton emphasised his connection with his murdered predecessor and the suffering they had both experienced at the hands of the Angevin kings.

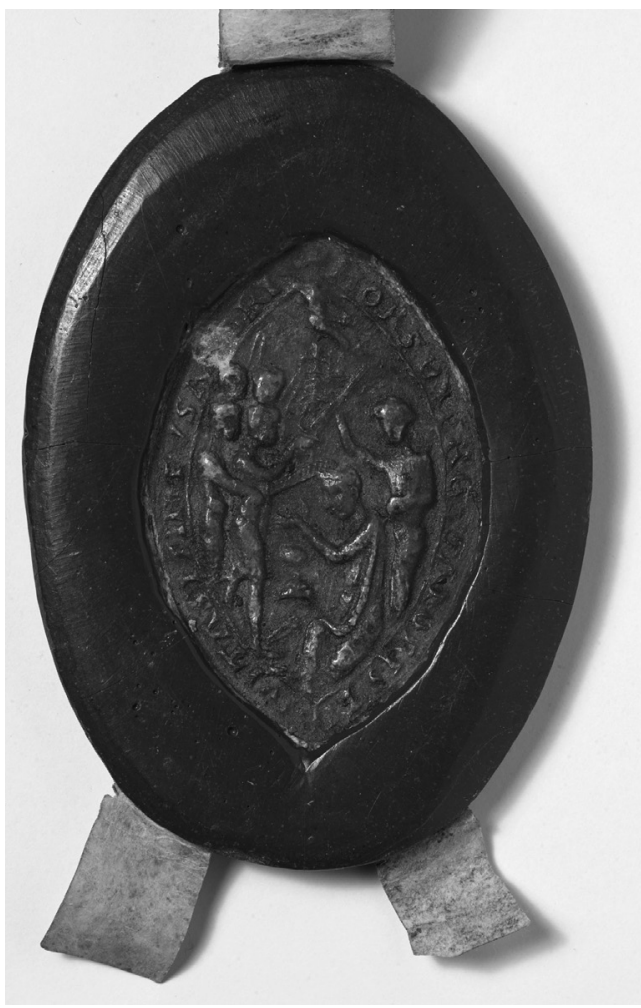


